\title{
Antibodies to a synthetic 1-9-N-terminal amino acid fragment of mature pediocin PA-1: sensitivity and specificity for pediocin PA-1 and cross-reactivity against Class Ila bacteriocins
}

\author{
José M. Martínez, María I. Martínez, Carmen Herranz, Ana Suárez, \\ María F. Fernández, Luis M. Cintas, Juan M. Rodríguez \\ and Pablo E. Hernández
}

Author for correspondence: Pablo E. Hernández. Tel: +34 91 3943752. Fax: + 34913943743.

e-mail: ehernan@eucmax.sim.ucm.es

Departamento de Nutrición y Bromatología III, Facultad de Veterinaria, Universidad Complutense, 28040 Madrid, Spain
Polyclonal antibodies specific for pediocin PA-1 (PedA1) were generated by immunization of rabbits with a chemically synthesized 1-9-N-terminal amino acid fragment of this bacteriocin (PH1) conjugated to the carrier protein keyhole limpet haemocyanin (KLH). The PH1 fragment holds a highly conserved amino acid sequence with closely related Class Ila bacteriocins. The sensitivity and specificity of the PH1-KLH-generated rabbit polyclonal antibodies were evaluated by the development of various ELISAs, such as a non-competitive indirect ELISA (NCI-ELISA), a competitive indirect ELISA (CI-ELISA), a competitive direct ELISA (CD-ELISA) and a sandwich ELISA (S-ELISA), and by protein slot-blotting and Western blotting. $\mathrm{NCl}$ - and $\mathrm{Cl}$-ELISA were valuable for detecting the existence of PedA1-specific antibodies in the sera of immunized rabbits. The limit of detection of PedA1 in MRS medium was found to be $0.5 \mu \mathrm{g}$ $\mathrm{ml}^{-1}$ in NCI-ELISA, while Cl-ELISA on plates coated with purified PedA1 increased the affinity of the PH1-KLH-generated antibodies for PedA1; the limit of detection of PedA1 was less than $0.01 \mu \mathrm{g} \mathrm{ml}^{-1}$ and $50 \%$ binding inhibition was achieved with $0.1 \mu \mathrm{g}$ PedA1 $\mathrm{ml}^{-1}$. Similarly, the limits of detection of PedA1 in MRS medium were found to be $5 \mu \mathrm{g} \mathrm{ml}^{-1}$ by protein slotblotting and $0.01 \mu \mathrm{g} \mathrm{ml}^{-1}$ by Western blotting. Most importantly, PH1-KLHgenerated polyclonal antibodies detected the presence of PedA1 in the supernatants of the producing strains of Pediococcus acidilactici 347, Z102, $A 172, X 13$ and P20, with no reactivity or negligible immunoreactivity with the supernatants of other lactic acid bacteria producing or not producing closely related or different bacteriocins. The approaches taken for the selection of the bacteriocin peptide fragment, the generation of antibodies and the development of immunoassays could prove useful for the generation and evaluation of antibodies of adequate specificity for other bacteriocins of interest in the food industry.

Keywords: pediocin PA-1, bacteriocin, immunodetection, lactic acid bacteria

\section{INTRODUCTION}

Many lactic acid bacteria (LAB) are known to secrete

Abbreviations: $A D T$, agar diffusion test; $C B$, coating buffer; $C D-, \mathrm{Cl}-, \mathrm{NCl}$ and S-ELISA, competitive direct, competitive indirect, non-competitive indirect and sandwich ELISA; KLH, keyhole limpet haemocyanin; LAB, lactic acid bacteria; MPA, microtitre plate assay; OA, ovalbumin; PedA1, pediocin PA-1; TMB, 3,3',5,5'-tetramethylbenzidine. small, ribosomally synthesized antimicrobial peptides called bacteriocins (Klaenhammer, 1993; Jack et al., 1995; Nes et al., 1996). Some of these peptides have received considerable attention in recent years due to their potential application in the food industry as natural food preservatives. The bacteriocins produced by $\mathrm{LAB}$ are often cationic, amphiphilic, membranepermeabilizing peptides classified into two main groups: Class I consisting of the modified bacteriocins, the 
lantibiotics, and Class II consisting of the unmodified peptide bacteriocins, such as the pediocin-like bacteriocins, the non-pediocin-like bacteriocins and the two-peptide bacteriocins (Nissen-Meyer \& Nes, 1997). A major subgroup of Class II bacteriocins (IIa) has been given the generic name of the pediocin-like family (Nes et al., 1996) after its most extensively studied member, pediocin PA-1 (PedA1). The pediocin-like family is the only grouping that has been classified by sequence similarities, and bacteriocins of this family share structural homologies and are composed of a conserved $\mathrm{N}$ terminal hydrophilic domain and a variable C-terminal domain (Aymerich et al., 1996; Casaus et al., 1997; Cintas et al., 1997). PedA1 has been characterized at the biochemical (Henderson et al., 1992; Nieto Lozano et al., 1992) and genetic (Marugg et al., 1992; Venema et al., 1995) levels. The mature PedA1 molecule is a 44 aa peptide with a molecular mass of $4629 \mathrm{Da}$ that contains four cysteine residues that participate in the formation of two disulfide bridges. The peptide is predicted to exist largely as a random coil, with only a small hydrophobic region in residues $21-25$ with a propensity to form a $\beta$ sheet (Klaenhammer, 1993).

Because of the potential use of bacteriocins as food preservatives and since most industrial strains do not produce such antagonistic peptides, interest in the heterologous expression or co-expression of Class II bacteriocins is growing rapidly (van Belkum et al., 1997; Biet et al., 1998; Horn et al., 1998). However, an adequate identification, detection and quantification of the bacteriocin(s) produced by the heterologous hosts is demanded. The use of a bioassay-based method that assesses the inhibitory effect of bacteriocins in a test or indicator micro-organism is the most commonly used tool for detection and quantification of bacteriocins. The importance of the bioassay is undeniable, but it also has some drawbacks, such as lack of specificity and low sensitivity. However, the antimicrobial efficiency of different methods of food preservation can be improved through the application of the hurdle concept (Leistner \& Gorris, 1995; Abriouel et al., 1998). Bacteriocins either alone or in combination with other antimicrobial barriers may be useful tools to substantially reduce the load of foodborne pathogens and food spoilage bacteria. However, bacteriocin preparations with adequate purity must be provided. Accordingly, the development of efficient detection, quantification and purification procedures for PedA1 and other bacteriocins could greatly facilitate their use as food preservatives. The generation of antibodies against bacteriocins may provide sensitive and specific methods for the identification and detection of producing strains and for the quantification of bacteriocins in different substrates by the use of immunochemical assays (Martínez et al., 1998). Antibodies also offer potential alternative methods for the purification of bacteriocins to homogeneity by the use of immunoaffinity chromatography strategies (Suárez et al., 1997).

The scarcity of appropriate immunochemical methods for use in the bacteriocin research field is most probably due to the difficulties encountered in raising antibodies and in the development of sensitive immunoassays. Reports on the generation of antibodies against bacteriocins have been scarce and have been based on the use of whole bacteriocin molecules, either alone or conjugated to carriers, as the immunogen (Bhunia et al., 1990; Falahaee et al., 1990; Bhunia, 1994; Stringer et al., 1995; Suárez et al., 1996a, b; Bouksaim et al., 1998). Recently, the use of a chemically synthesized fragment deduced from the C-terminal amino acid sequence and unique to PedA1 has facilitated the development of antibodies of predetermined specificity against PedA1 (Martínez et al., 1998). However, the specificity of antibodies generated against bacteriocin sequences sharing strong consensus similarities has not been evaluated yet. We report in this communication the sensitivity and specificity of antibodies generated against a synthetic 1-9-N-terminal amino acid fragment of PedA1, a short peptide with a strong amino acid sequence homology with Class IIa bacteriocins and the development of sensitive immunoassays for PedA1 analysis.

\section{METHODS}

Materials. The amino acid sequence of the $\mathrm{N}$-terminal fragment of PedA1 (peptide PH1) used in this work was $\mathrm{NH}_{2}{ }^{-}$ KYYGNGVTC-COOH. Peptide PH1 (residues 1-9, 1104 Da, $30 \mathrm{mg}$ ) was synthesized by Fmoc chemistry with an Applied Biosystems 431A automated solid-phase peptide synthesizer in the Protein Chemistry Facility at the Centro de Biología Molecular Severo Ochoa, Madrid, Spain. Purity of the peptide was monitored by RP-HPLC, being higher than $95 \%$, and peptide identity was confirmed by MS. A chemically synthesized fragment corresponding to the C-terminal region of PedA1 (peptide PH2, residues 34-44, $1009 \mathrm{Da}, 10 \mathrm{mg}$ ) was used as a control. The amino acid sequence of peptide $\mathrm{PH} 2$ was $\mathrm{NH}_{2}$-ATGGHQGNHKC-COOH. Ovalbumin (OA) (grade III and fraction VII), horseradish peroxidase (HRP) (fraction VI), Tween 20, glutaraldehyde and Freund's adjuvants were obtained from Sigma. The Imject Activated Immunogen Conjugation Kit containing maleimide-activated keyhole limpet haemocyanin (KLH), maleimide-activated OA, conjugation buffer and gel filtration columns was obtained from Pierce. Goat anti-rabbit immunoglobulin $G$ conjugated to horseradish peroxidase was obtained from Cappel. Pure nisin A (30000 $\mathrm{U} \mathrm{mg}^{-1}$ ) was purchased from NBS Biologicals. Rabbits (New Zealand white females) were purchased from a local supplier (Navarra, Spain).

Preparation of immunoconjugates and immunization. PH1 was conjugated to maleimide-activated KLH (PH1-KLH, 1:2, $\mathrm{w} / \mathrm{w}$ ) using the components of the Imject Activated Immunogen Conjugation Kit, for use as the immunogen. The chemically synthesized PH1 fragment was also conjugated to maleimide-activated OA (PH1-OAM, 12.5:1, mol $/ \mathrm{mol}$ ) and to OA (PH1-OAG, 12:1, mol/mol) by the glutaraldehyde method (Avrameas \& Ternynck, 1969; Briand et al., 1985) for use as a solid-phase antigen. Peptide PH2 was also conjugated to $\mathrm{OA}$ by the glutaraldehyde method (PH2-OAG, 12.5:1, $\mathrm{mol} / \mathrm{mol}$ ) for use as a solid-phase antigen. PH1 and purified PedA1 were also conjugated to horseradish peroxidase (PH1HRP, 1:5, w/w; PedA1-HRP, 1:5, w/w) by the periodate method (Nakane \& Kawoi, 1974) for use in competitive direct ELISAs. Rabbits were immunized with PH1-KLH according 
Table 1. Reactivities of serum polyclonal antibodies against culture supernatants of $L A B$ as determined by a NCI-ELISA and CI-ELISA

\begin{tabular}{|c|c|c|c|}
\hline \multirow[t]{2}{*}{ Strain (bacteriocin produced) } & \multirow[t]{2}{*}{ Source* } & \multicolumn{2}{|c|}{ Cross-reactivity $(\%)$} \\
\hline & & NCI-ELISA † & CI-ELISA $\ddagger$ \\
\hline P. acidilactici 347 (PedA1) & Our collection & $76 \cdot 1$ & $99 \cdot 3$ \\
\hline P. acidilactici Z102 (PedA1) & Our collection & 100 & $99 \cdot 4$ \\
\hline P. acidilactici A172 (PedA1) & Our collection & $83 \cdot 7$ & $99 \cdot 2$ \\
\hline P. acidilactici X13 (PedA1) & Our collection & $90 \cdot 7$ & 100 \\
\hline P. acidilactici P20 (PedA1) & Our collection & $4 \cdot 5$ & 8 \\
\hline P. acidilactici $347 \mathrm{Ped}^{-}$(non-PedA1 producer) & Our collection & NR & NR \\
\hline P. pentosaceus FBB61 (pediocin A) & TNO & NR & NR \\
\hline E. faecium T136 (enterocin A and B) & Our collection & $2 \cdot 9$ & $4 \cdot 2$ \\
\hline E. faecium P13 (enterocin P) & Our collection & NR & NR \\
\hline Lb. sakei LTH673 (sakacin P) & NHL & NR & $\mathrm{NR}$ \\
\hline Lb. sakei 706 (sakacin A) & NHL & NR & NR \\
\hline E. faecium L50 (enterocin L50A and L50B) & Our collection & NR & $0 \cdot 6$ \\
\hline E. faecalis INIA4 (enterocin AS-48) & INIA & $2 \cdot 1$ & NR \\
\hline Lb. sakei 148 (lactocin S) & Our collection & NR & NR \\
\hline Lc. lactis BB24 (nisin A) & Our collection & $3 \cdot 9$ & NR \\
\hline Lc. lactis MG1614 (non-bacteriocin producer) & IFR & NR & $1 \cdot 2$ \\
\hline
\end{tabular}

NR, No reactivity.

*IFR, Institute of Food Research, Norwich Laboratory, Norwich, UK; INIA, Instituto Nacional de Investigación y Tecnología Agraria y Alimentaria, Madrid, Spain; TNO, Nutrition and Food Research, Zeist, The Netherlands; NHL, Laboratory of Microbial Gene Technology, Agricultural University, Ås, Norway.

† Cross-reactivity defined as [(absorbance reading produced by a culture supernatant above the absorbance reading produced by MRS/absorbance reading produced by supernatant of $P$. acidilactici Z102 above the absorbance reading produced by MRS) $\times 100]$.

$\ddagger$ Cross-reactivity defined as [ (antibody binding inhibition produced by a culture supernatant above the antibody binding inhibition produced by supernatant of $P$. acidilactici $\mathrm{Ped}^{-} /$antibody binding inhibition produced by supernatant of $P$. acidilactici X13 above the antibody binding inhibition produced by supernatant of $P$. acidilactici $\mathrm{Ped}^{-}$) $\left.\times 100\right]$.

to a previously described scheme (Martínez et al., 1998). Rabbits were bled via marginal ear veins on days 28 and 63 and a final bleed was performed on day 72 by cardiac puncture.

ELISAs. Most of the procedures were performed as previously described (Martínez et al., 1998). Briefly, for antisera titration flat-bottom polystyrene microtitre plates (Maxisorp) were coated overnight $\left(4^{\circ} \mathrm{C}\right)$ with $100 \mu \mathrm{l} \mathrm{PH} 1-\mathrm{OAG}\left(5 \mu \mathrm{g} \mathrm{m}^{-1}\right)$ in $0 \cdot 1 \mathrm{M}$ sodium carbonate/bicarbonate buffer, $\mathrm{pH} 9 \cdot 6$ (coating buffer, CB). Plates were washed three times with $300 \mu \mathrm{l}$ washing solution $(0.05 \%$ Tween 20 in PBS). Wells were blocked for $30 \mathrm{~min}$ at $37{ }^{\circ} \mathrm{C}$ with $300 \mu \mathrm{l} 1 \%$ (w/v) OA (grade III) in PBS (OA-PBS) and then washed six times. Next, $50 \mu \mathrm{l}$ serially diluted serum was added to each well and incubated for $1 \mathrm{~h}$ at $37^{\circ} \mathrm{C}$. Unbound antibody was removed by washing four times and $100 \mu$ l goat anti-rabbit $\mathrm{IgG}$ peroxidase conjugate (diluted 1:500 in OA-PBS) was added to each well. Plates were incubated for $30 \mathrm{~min}$ at $37^{\circ} \mathrm{C}$, washed eight times and bound peroxidase was determined with ABTS [2,2'-azinobis(3-ethylbenzothiazoline-6-sulfonic acid] as substrate by measuring $A_{405}$. The titre of each serum was arbitrarily set as the maximum dilution that yielded at least twice the absorbance of the same dilution of non-immune control serum.

For antiserum specificity and sensitivity to PedA1, four types of ELISA were designed. In non-competitive indirect ELISA
(NCI-ELISA) wells of microtitre plates were coated with $100 \mu \mathrm{l}$ of different concentrations of the analytes. The plates were maintained for $3 \mathrm{~h}$ at $40{ }^{\circ} \mathrm{C}$, then blocked and washed as described for the antiserum titration procedure. Next, $50 \mu \mathrm{l}$ antiserum, diluted 1:200 in PBS, was added and the plates incubated for $1 \mathrm{~h}$ at $37^{\circ} \mathrm{C}$. After the washing step and addition of the goat anti-rabbit IgG peroxidase conjugate (diluted $1: 500$ in OA-PBS), the bound peroxidase was determined with ABTS substrate as described above. In competitive indirect ELISA (CI-ELISA), microtitre plates were coated with $100 \mu \mathrm{l}$ of either PH1-OAG or PedA1, both at $0.75 \mu \mathrm{g} \mathrm{m}^{-1}$ in CB, and blocked and washed as described for the antiserum titration procedure. Next, $50 \mu \mathrm{l}$ of different concentrations of the analytes was simultaneously incubated with $50 \mu \mathrm{l}$ antiserum (diluted 1:250 in PBS) for $1 \mathrm{~h}$ at $37^{\circ} \mathrm{C}$. After the washing step and addition of the goat anti-rabbit IgG peroxidase conjugate (diluted 1:500 in OA-PBS), the bound peroxidase was

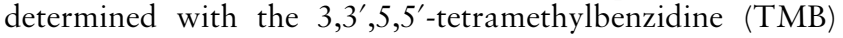
liquid substrate system (Sigma). $A_{450}$ was measured after acidification of the samples with $100 \mu \mathrm{l}$ of a $1 \mathrm{M} \mathrm{H}_{2} \mathrm{SO}_{4}$ stopping solution. Relative antibody affinity was arbitrarily designated as the bacteriocin concentration required to inhibit antibody binding by $50 \%$.

A competitive direct ELISA (CD-ELISA) was also developed. In this assay, the plates were coated overnight by air drying at 
$40{ }^{\circ} \mathrm{C}$ with $125 \mu \mathrm{l} \mathrm{PH1-KLH-generated} \mathrm{antibodies} \mathrm{(diluted}$ $1: 100$ in $\mathrm{CB}$ ). After washing and blocking, $50 \mu \mathrm{l}$ of the analytes and $50 \mu \mathrm{l}$ of either PH1-HRP (diluted 1:100) or PedA1-HRP (diluted 1:100) in OA-PBS, was added to each well consecutively. After $1 \mathrm{~h}$ incubation at $37^{\circ} \mathrm{C}$, the plates were washed and the amount of bound peroxidase was determined by addition of the TMB substrate. For sandwich ELISA (SELISA), the plates were coated overnight by air drying at $40{ }^{\circ} \mathrm{C}$ with $125 \mu \mathrm{l}$ of the goat anti-rabbit IgG Fc fragment (diluted 1:540 in CB). After washing and blocking, $50 \mu \mathrm{l}$ PH1-KLH-generated antibodies diluted 1:150 in PBS were added. After $30 \mathrm{~min}$ incubation at $37^{\circ} \mathrm{C}$ the plates were washed and $50 \mu \mathrm{l}$ standards, control samples or samples were added per well. After $45 \mathrm{~min}$ incubation at $37^{\circ} \mathrm{C}$, the plates were washed and $50 \mu \mathrm{l}$ mouse PH2-KLH-generated antibodies (J. M. Martínez, M. I. Martínez, C. Herranz, L. M. Cintas, J. M. Rodríguez \& P. E. Hernández, unpublished results) diluted $1: 100$ in PBS was added. After another $45 \mathrm{~min}$ incubation at $37^{\circ} \mathrm{C}$, the washing step and the addition of goat anti-mouse IgG peroxidase conjugate (diluted 1:500 in OA-PBS), the plates were washed and the amount of bound peroxidase was determined by addition of TMB substrate.

Protein slot-blot assay. Eighty microlitres of different concentrations of PH1-OAG, PH2-OAG, OA, PedA1 or pure nisin A dissolved in MRS, and the same volume of neutralized and filter-sterilized supernatants from $16 \mathrm{~h}$ cultures of various $\mathrm{LAB}$, were deposited onto a nitrocellulose membrane (pore size, $0.2 \mu \mathrm{m}$; Bio-Rad) in a Bio-dot SF microfiltration apparatus (Bio-Rad) and the membrane was processed essentially as described previously (Martínez et al., 1998). The membrane was incubated with $30 \mathrm{ml} \mathrm{PH1-KLH}$ antiserum (diluted 1:200 in PBS) and further incubated with $30 \mathrm{ml}$ goat anti-rabbit $\operatorname{IgG}$ peroxidase conjugate (diluted 1:5000 in blocking solution). Specific antigens for PH1-KLH-generated antibodies were visualized by chemiluminescence with the ECL detection kit (Amersham). The light emission was detected by a short exposure of the membrane to a blue-lightsensitive autoradiography film (Hyperfilm ECL, Amersham).

Protein electrophoresis, Western hybridization and overlay assay. Fifteen microlitres of pure PedA1 (0.02, 0.001, 0.005 and $0.002 \mu \mathrm{g} \mathrm{ml}^{-1}$ ) and the supernatants from $16 \mathrm{~h}$ cultures of Pediococcus acidilactici $347\left(\mathrm{Ped}^{-}\right)$, P acidilactici 347, Enterococcus faecium T136, E. faecium P13, Lactobacillus sakei 706, Lb. sakei LTH673, Lactococcus lactis BB24, Lc. lactis FI9181 (Lc. lactis IL1403 derivative, producer of PedA1; N. Horn, M. I. Martínez, J. M. Martínez, P. E. Hernández, M. J. Gasson, J. M. Rodríguez \& H. Dodd, unpublished results) and Lc. lactis IL1403 were subjected to Tricine-SDS-PAGE (Shägger \& Von Jagow, 1987). After protein electrophoresis, one of the gels was blotted onto a PVDF membrane (pore size, $0 \cdot 2 \mu \mathrm{m}$; Bio$\mathrm{Rad}$ ) by the application of an electrical potential of $80 \mathrm{mV}$ for $50 \mathrm{~min}$. Further blocking and washing of the PVDF membrane, treatment with the PH1-KLH antiserum and goat anti-rabbit $\operatorname{IgG}$ peroxidase conjugate and visualization of the expected antigen-antibody interaction by chemiluminescence with an ECL detection kit were performed as described above for the protein slot-blot assay. To determine the antimicrobial activity of pure PedA1 and the supernatants of the tested strains, an overlay assay was performed (Bhunia et al., 1987). After the gel was fixed, washed and drained it was overlaid with the indicator strain $L b$. sakei ATCC $15521\left(1 \times 10^{5}\right.$ c.f.u. $\mathrm{ml}^{-1}$ in soft agar) and incubated overnight at $30^{\circ} \mathrm{C}$.

Micro-organisms, media and bacteriocin assays. The LAB tested for PedA1 production or antibody cross-reactivity are listed in Table 1. All micro-organisms were propagated in
MRS broth (Oxoid) at $32{ }^{\circ} \mathrm{C}$ and the supernatants were obtained by centrifugation at $12000 \mathrm{~g}$ for $10 \mathrm{~min}$ at $4{ }^{\circ} \mathrm{C}$, adjusted to $\mathrm{pH} 6.2$ with $1 \mathrm{M} \mathrm{NaOH}$, filtering through $0.2 \mu \mathrm{m}$ pore filters (Whatman) and stored at $-20{ }^{\circ} \mathrm{C}$ until use. The antimicrobial activity of the supernatants was evaluated by an agar diffusion test (ADT) and, when stated, by a microtitre plate assay (MPA). The ADT and the MPA assays were performed as described previously (Martínez et al., 1998).

Purification of PedA1. The antimicrobial activity of $P$. acidilactici 347, used as the source of PedA1, was purified to homogeneity as described previously (Cintas et al., 1997; Horn et al., 1998; Martínez et al., 1998). The final concentration of pure bacteriocin was estimated by using the extinction coefficient of PedA1 $\left(A_{280}\right.$ of $3 \cdot 1$ corresponds to $\left.1 \mathrm{mg} \mathrm{ml}^{-1}\right)$.

\section{RESULTS}

\section{Sensitivity of rabbit antipeptide antibodies for PedA1}

The PH1 fragment conjugated to KLH was used in the immunization of rabbits. On day 72 of the immunization process and after six doses of the immunogen had been administered, the animals had apparent titres in the serum of $1: 25600,1: 51200$, and $1: 102400$. The serum with the highest titre for fragment PH1 was used throughout. The sensitivity of the anti-PH1-KLH antibodies for PedA1 was initially determined by NCIELISA. As seen in Fig. 1, the polyclonal antibodies showed a higher recognition of the peptide fragment

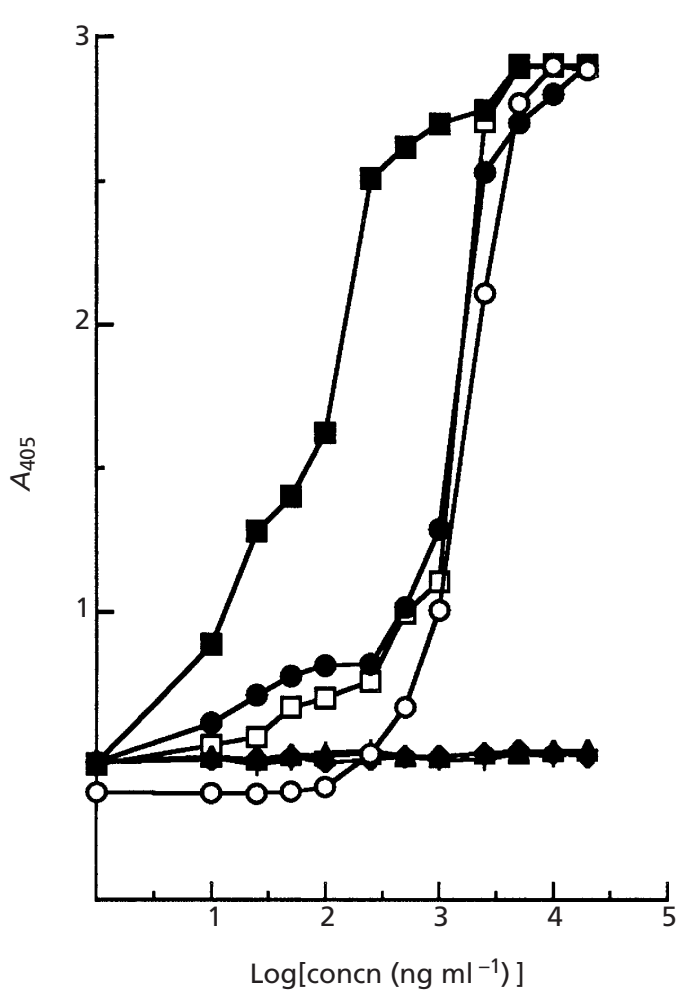

Fig. 1. Results of NCl-ELISA for the detection of PH1-OAM ( $\square$ ), PH1-OAG (0), PH2-OAG $(\boldsymbol{\Delta})$, purified PedA1 in CB $(\square)$, purified PedA1 in MRS $(O)$, pure nisin $A$ in $C B(\diamond)$ and pure $O A$ in $\mathrm{CB}(+)$. 


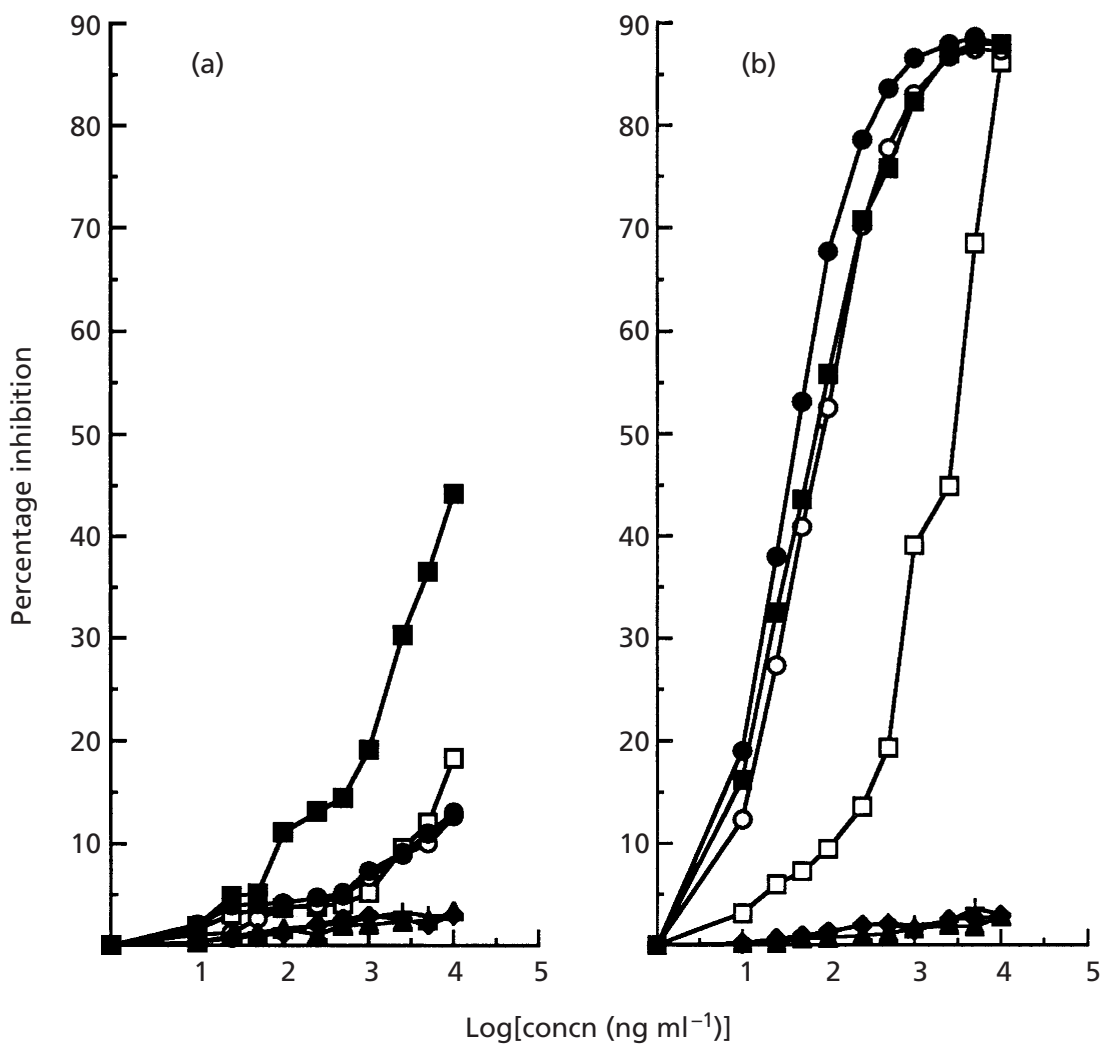

Fig. 2. Results of CI-ELISA for recognition of the PH1 fragment in PBS ( $\square$ ) and MRS (0), and purified PedA1 in PBS $(\square)$ and MRS (O), as well as for recognition of the $\mathrm{PH} 2$ fragment $(\boldsymbol{A})$, pure $\mathrm{OA}(+)$ and pure nisin $A$ $(\diamond)$ in PBS, using microtitre ELISA plates coated with PH1-OAG (a) or purified PedA1 (b).

conjugated to OA through the maleimide method (PH1-OAM) than to the fragment conjugated to OA by the glutaraldehyde method (PH1-OAG), suggesting that a large number of antibodies recognized the same chemical bridge between the peptide fragment and KLH. More importantly, the antibodies recognized PedA1 present in the wells of the microtitre plates, although recognition was higher for PedA1 in CB $\left(0 \cdot 05 \mu \mathrm{g} \mathrm{ml}^{-1}\right)$ than in MRS broth $\left(0.5 \mu \mathrm{g} \mathrm{ml}^{-1}\right)$. Such antibodies could not detect the presence of equivalent concentrations of $\mathrm{OA}, \mathrm{PH} 2-\mathrm{OAG}$ or pure nisin $\mathrm{A}$ in the wells of the microtitre plates.

The specificity for PedA1 of the PH1-KLH-generated antibodies was also investigated by a CI-ELISA. The mean detection limit for fragment PH1 was much higher on plates coated with PedA1 $\left(0 \cdot 01 \mu \mathrm{g} \mathrm{ml}^{-1}\right.$; Fig. $\left.2 \mathrm{~b}\right)$ than with PH1-OAG $\left(0 \cdot 1-1 \mu \mathrm{g} \mathrm{ml}{ }^{-1}\right.$; Fig. 2a), while for PedA1 the detection limits were $1-2.5 \mu \mathrm{g} \mathrm{ml}^{-1}$ in PBS and $1 \mu \mathrm{g} \mathrm{ml}^{-1}$ in MRS broth on plates coated with PH1OAG, and 0.01-0.025 $\mu \mathrm{g} \mathrm{ml}^{-1}$ in PBS and $0.01 \mu \mathrm{g} \mathrm{m} l^{-1}$ in MRS broth on plates coated with PedA1. The amount of free $\mathrm{PH} 1$ required for $50 \%$ binding inhibition was not measurable on plates with PH1-OAG: $0 \cdot 1 \mu \mathrm{g} \mathrm{m}{ }^{-1}$ in PBS and $0.05 \mu \mathrm{g} \mathrm{ml}^{-1}$ in MRS broth on plates coated with PedA1. Similarly, the amount of free PedA1 for $50 \%$ binding inhibition was not measurable on plates coated with PH1-OAG: $2.5 \mu \mathrm{g} \mathrm{ml}^{-1}$ in PBS and of $0 \cdot 01 \mu \mathrm{g} \mathrm{ml}^{-1}$ in MRS broth on plates coated with PedA1. Thus, the performance of this assay is tremendously improved when PedA1 was used as the solid-phase antigen, thus increasing the relative antibody-binding affinity and decreasing the free PedA1 concentration required to inhibit antibody binding.

A CD-ELISA was also developed to determine the specificity of the PH1-KLH-generated antibodies for PedA1. In this assay, the plates were coated with an appropriate dilution of the serum of immunized animals and with HRP conjugated to either PH1 or PedA1. However, PedA1 did not effectively compete with either PH1-HRP or PedA1-HRP for binding to the antibodycoated microtitre wells (results not shown). Similarly, the development of S-ELISA for evaluation of the specificity of the antipeptide antibodies for PedA1 was also unsuccessful (results not shown), since it was not possible to observe an increase in the absorbance of the assay with increasing concentrations of PedA1 (until $10 \mu \mathrm{g} \mathrm{ml}^{-1}$ ).

\section{Immunoreactivity of the rabbit antipeptide antibodies to different bacteriocins}

The specificities of the serum polyclonal antibodies in neutralized and filter-sterilized supernatants of 16-h-old cultures of representative $\mathrm{LAB}$ strains were evaluated by NCI- and CI-ELISA (Table 1). The antibodies in both immunoassays reacted with the supernatants of the $P$. acidilactici strains 347, Z102, A172, X13 and P20, all potential PedA1 producers since they have been reported to harbour the pedA gene by the use of rapid molecular biology techniques (Rodríguez et al., 1997), but did not react with the supernatant of a derivative of $P$. acidilactici $347\left(\mathrm{Ped}^{-}\right)$, a non-PedA1 strain (Martínez et 
Table 2. Multiple sequence alignment of mature PedA1 with other Class Ila bacteriocins

The bar refers to the sequence of fragment PH1 of PedA1 against which the polyclonal antibodies were generated. Sequences were obtained from the following: piscicocin V1a, Bhugaloo-Vial et al. (1996); divercin V41, Metivier et al. (1998); mundticin, Bennik et al. (1998); all others, Martínez et al. (1998).

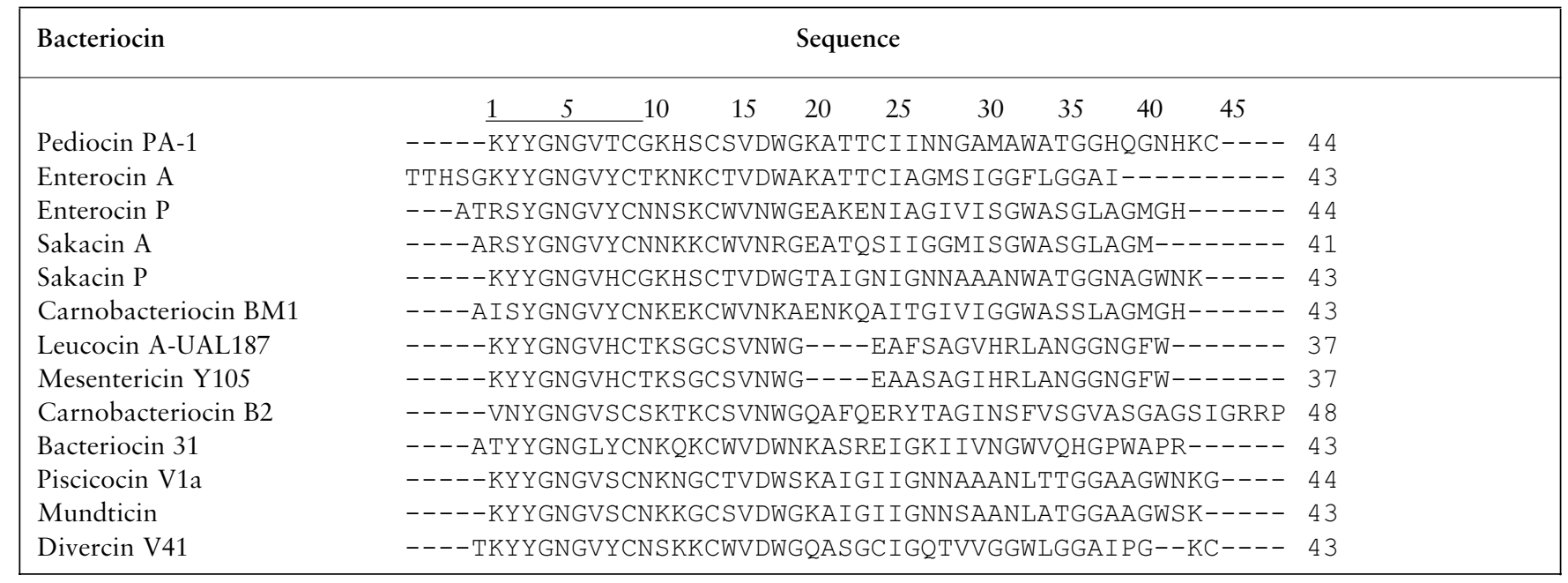

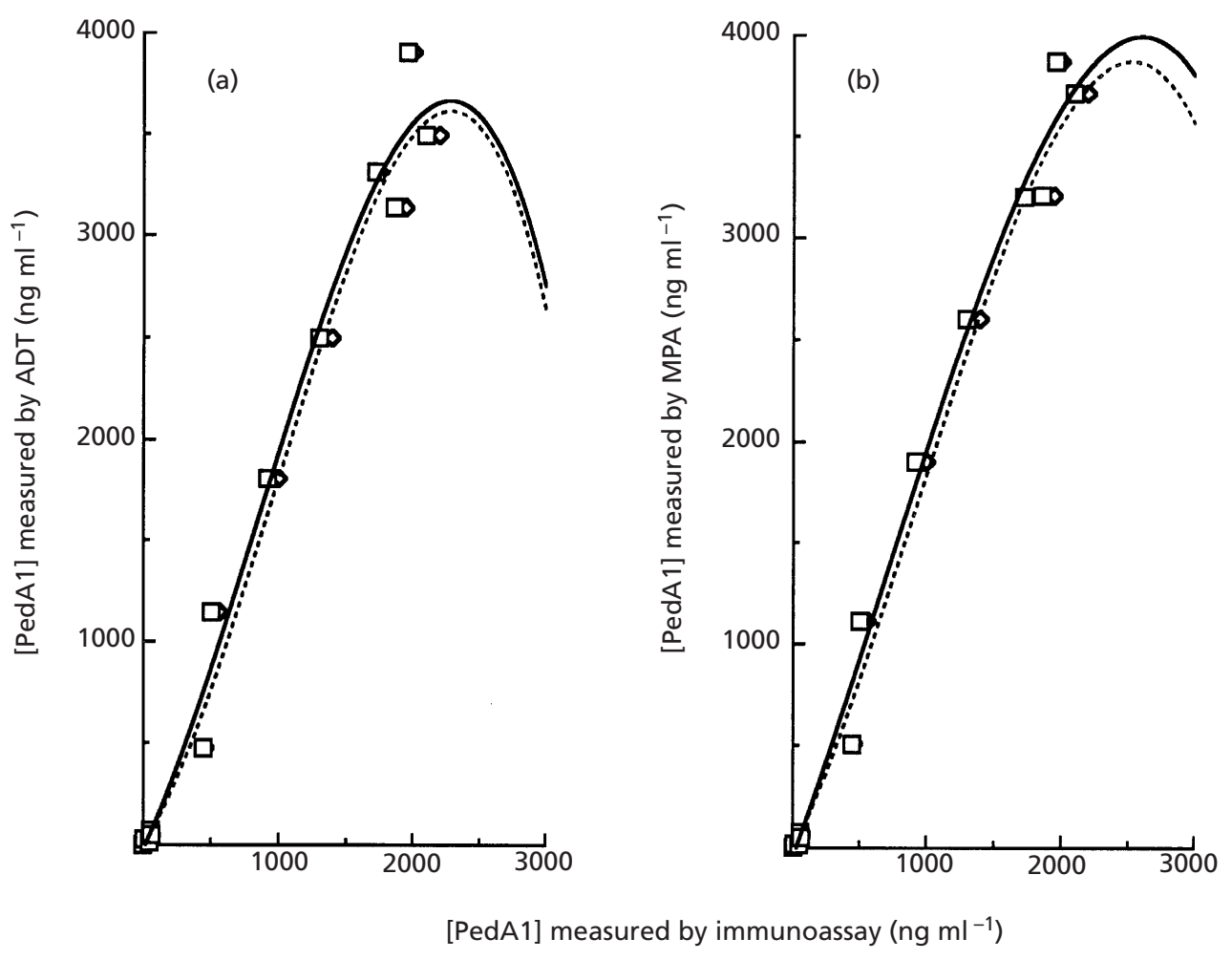

Fig. 3. Relationship between PedA1 concentrations by ADT (a) and MPA (b), and by NCI- $(\square)$ and CI-ELISA ( $\diamond)$. The resulting regression equations are: (a) $Y_{\mathrm{NCI} \text {-ELISA }}=-19 \cdot 211+1 \cdot 4305 x+8.7312 \mathrm{e}-4 x^{2}-3.4726 \mathrm{e}-7 x^{3}\left(r^{2}=0.986\right), Y_{\text {CI-ELISA }}=$ $-9.7686+1.0798 x+1.1410 \mathrm{e}-3 x^{2}-4.0248 \mathrm{e}-7 x^{3}\left(r^{2}=0.985\right) ;$ and $(\mathrm{b}) Y_{\text {NCI-ELISA }}=-37.931+1.7645 x+4.3088 \mathrm{e}-4 x^{2}-1.9740 \mathrm{e}-7 x^{3}$ $\left(r^{2}=0.990\right), Y_{\text {CI-ELISA }}=-28 \cdot 544+1 \cdot 4030 x+7 \cdot 1950 \mathrm{e}-4 x^{2}-2 \cdot 6280 \mathrm{e}-7 x^{3}\left(r^{2}=0.991\right)$.

al., 1998). However, the reactivity for the P. acidilactici P20 strain was much lower than for the other $P$. acidilactici strains. A much lower reactivity, negligible reactivity or no reactivity was observed with the supernatants of Pediococcus pentosaceus FBB61, a pediocin A producer (Piva \& Headon, 1994), E. faecium 
Table 3. PedA1 concentration in culture supernatants of PedA1 producers as determined by $\mathrm{Cl}$-ELISA

\begin{tabular}{|c|c|}
\hline P. acidilactici strain & 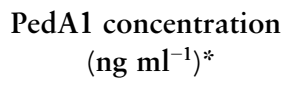 \\
\hline 347 & 1972 \\
\hline Z102 & 2005 \\
\hline A172 & 1946 \\
\hline $\mathrm{X} 13$ & 2200 \\
\hline P20 & 12 \\
\hline $347 \mathrm{Ped}^{-}$(non-PedA1 producer) & NR \\
\hline
\end{tabular}

* Mean value from four independent determinations. NR, No reactivity.

T136, an enterocin A and B producer (Casaus et al., 1997), E. faecium P13, an enterocin P producer (Cintas et al., 1998), Lb. sakei LTH673, a sakacin P producer (Tichaczek et al., 1994), Lb. sakei 706, a sakacin A producer (Holck et al., 1992), E. faecium L50, an enterocin L50A and L50B producer (Cintas et al., 1998), Lb. sakei 148, a lactocin S producer (Rodríguez et al., 1995a), Lc. lactis BB24, a nisin A producer (Rodríguez et al., 1995b) and Lc. lactis MG1614, a non-bacteriocin producer (Gasson, 1983). Table 2 shows the amino acid sequence alignment of mature PedA1 with other Class IIa bacteriocins. It is important to note that enterocin A, sakacin $\mathrm{P}$, leucocin $\mathrm{A}$, mesentericin $\mathrm{Y} 105$, piscicocin $\mathrm{V} 1 \mathrm{a}$, mundticin and divercin V41 share the longer $\mathrm{N}$ terminal consensus amino acid motif (KYYGNGVxC) of the pediocin family of bacteriocins, while enterocin $\mathrm{P}$, sakacin A, carnobacteriocin BM1, carnobacteriocin B2 and bacteriocin 31 share the shorter (YGNGVxC) motif.

The concentration of PedA1 in the supernatant of a 16h-old culture of $P$. acidilactici 347 grown in MRS broth was evaluated by NCI- and CI-ELISA, and by the bioassay-based antimicrobial tests ADT and MPA. The concentrations of PedA1 were determined to be $3198 \mathrm{ng}$ $\mathrm{ml}^{-1}$ by the MPA and $3310 \mathrm{ng} \mathrm{ml}^{-1}$ by ADT, while the PedA1 concentrations were lower but similar in NCIELISA (1724 $\mathrm{ng} \mathrm{ml}^{-1}$ ) and CI-ELISA (1972 $\mathrm{ng} \mathrm{ml}^{-1}$ ). With the use of the previously described PH2-KLHgenerated antibodies (Martínez et al., 1998), the concentrations of PedA1 in the same supernatant were determined to be $1670 \mathrm{ng} \mathrm{ml}^{-1}$ by NCI-ELISA, $1689 \mathrm{ng}$ $\mathrm{ml}^{-1}$ by CI-ELISA and $1701 \mathrm{ng} \mathrm{ml}^{-1}$ by CD-ELISA. The differences in PedA1 concentrations as determined by the immunoassays and the bioassays may be attributed to the fact that the purified PedA1 used as the standard in both assays may have a lower activity than the native PedA1 present in the supernatants. For this reason, the haloes generated by the native PedA1 may be larger than those generated by the purified PedA1, magnifying the true concentration of PedA1 in the supernatants. Since the immunoassays detect and quantify PedA1 independently of their activity, the results obtained with the immunoassays are probably more suitable for evaluating the real concentrations of PedA1 in the supernatants of

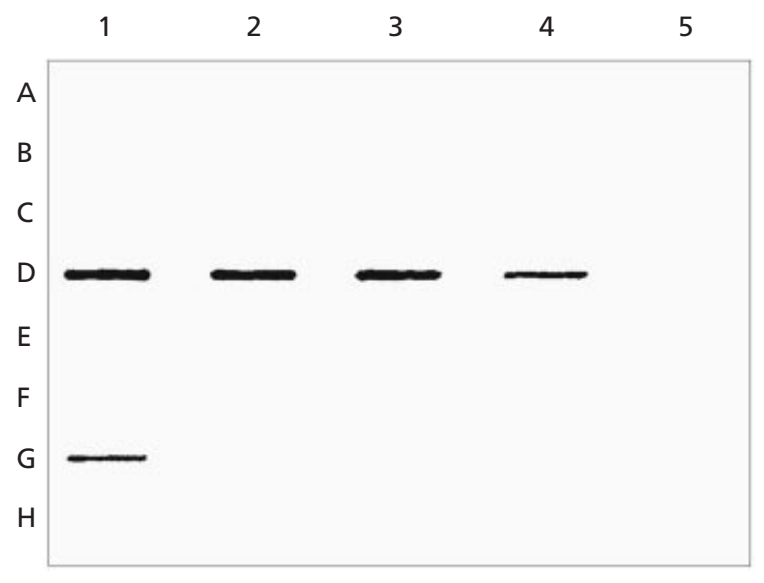

Fig. 4. Slot-blot of various standards and supernatants from LAB. Row A: supernatants from $P$. acidilactici 347 (lane 1), $P$. acidilactici Z102 (2), P. acidilactici X13 (3), P. acidilactici A172 (4) and $P$. acidilactici P20 (5). Row B: supernatants from $P$. acidilactici $347\left(\mathrm{Ped}^{-}\right)$(1), E. faecium L50 (2), P. pentosaceus FBB61 (3), E. faecium P13 (4) and E. faecium T136 (5). Row C: supernatants from $E$. faecalis INIA4 (1), Lb. sakei 148 (2), LC. lactis BB24 (3), Lb. sakei 706 (4) and Lb. sakei LTH673 (5). Row D: PH1-OAG at 5 (1), 2.5 (2), 1 (3), 0.5 (4) and $0 \mu \mathrm{g} \mathrm{m}^{-1}$ (5). Rows $\mathrm{E}, \mathrm{PH} 2-\mathrm{OAG}$; $\mathrm{F}$, pure $\mathrm{OA} ; \mathrm{G}$, purified PedA1; $\mathrm{H}$, pure nisin $A$ (concentrations in lanes $1-5$ in rows $E-H$ as for row $D$, all in MRS).

the producer strains. The relationship between ADT (Fig. 3a) and MPA (Fig. 3b), and NCI-ELISA and CIELISA, using PH1-KLH-generated antibodies was also evaluated. Significant $(P<0 \cdot 001)$ regression equations could be established for PedA1 concentrations detected by ADT and the immunoassays $\left(r^{2}, 0.986-0.985\right)$ and by MPA and the immunoassays $\left(r^{2}, 0 \cdot 991-0 \cdot 990\right)$. CI-ELISA was also used to determine the concentrations of PedA1 in the supernatants of the five independently isolated $P$. acidilactici strains (Table 3). While most of the strains displayed a similar production of PedA1, P. acidilactici P20 produced a significantly lower concentration of this bacteriocin, resolving the usefulness of this assay to detect and quantify low concentrations of PedA1. The PH1-KLH-generated antibodies and CI-ELISA also demonstrated their usefulness to quantify the heterologous production of PedA1 (from 30 to $1908 \mathrm{ng} \mathrm{ml}^{-1}$ ) by a number of genetically modified Lc. lactis IL1403 derivatives (N. Horn, M. I. Martínez, J. M. Martínez, P. E. Hernández, M. J. Gasson, J. M. Rodríguez \& H. Dodd, unpublished results).

The immunoreactivity of the PH1-KLH-generated antibodies to different conjugates, standards and bacteriocins was also evaluated by protein slot-blotting. Results of a slot-blot peptide assay of standards and supernatants of 16 -h-old cultures of various LAB strains probed with the cited antibodies (Fig. 4), indicated that the antibodies recognized fragment PH1, but not fragment $\mathrm{PH} 2$, OA or pure nisin A. Similarly, the antibodies recognized pure PedA1 at a detection limit of $5 \mu \mathrm{g} \mathrm{ml} l^{-1}$, with a non-detectable response signal in the supernatants of $P$. acidilactici 347, X13, Z102, A172 and P20, 
(a)

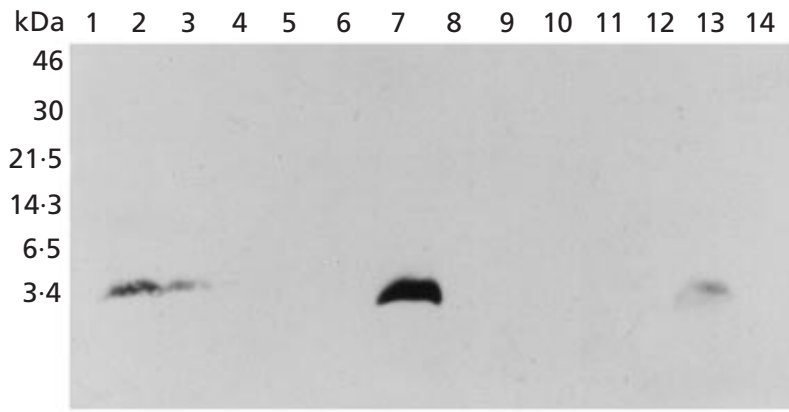

(b)

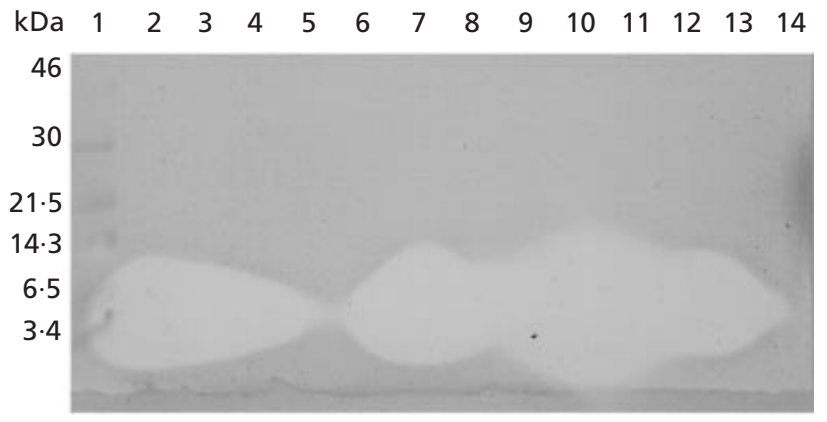

Fig. 5. Tricine-SDS-PAA gel: (a) Western blot and (b) overlaid with the indicator strain Lb. sakei ATCC 15521. Lane 1, molecular mass marker. Lanes 2 to 5 contain pure PedA1 at 0.02 (2), 0.01 (3), 0.005 (4) and $0.002 \mu \mathrm{g} \mathrm{ml}^{-1}$ (5). Lanes 6 to 14 contain supernatants from $P$. acidilactici $347 \mathrm{Ped}^{-}(6), P$. acidilactici 347 (7), E. faecium T136 (8), E. faecium P13 (9), Lb. sakei 706 (10), Lb. sakei LTH673 (11), Lc. lactis BB24 (12), Lc. lactis FI9181 (13) and Lc. lactis IL1403 (14).

as well as in the supernatants of different bacteriocin producer or non-producer LAB strains. Finally, a Western hybridization assay was also evaluated to determine the immunoreactivity of rabbit antipeptide antibodies to PedA1. The results obtained with purified PedA1 and supernatants from 16-h-old cultures of various LAB strains probed with PH1-KLH-generated antibodies (Fig. 5a) clearly indicated that the antibodies recognized PedA1 at a detection limit of $0.01 \mu \mathrm{g} \mathrm{ml} l^{-1}$, being able to detect the presence of this bacteriocin in the supernatants of $P$. acidilactici 347 and Lc. lactis FI9181, with no reactivity from supernatants of Class IIa bacteriocin producer or non-producer LAB strains. The presence of active bacteriocins in the supernatants was demonstrated by the results of the overlay assay as shown in Fig. 5 b.

\section{DISCUSSION}

Contrary to the situation for other analytes, the identification and detection of bacteriocinogenic LAB and bacteriocins has relied mostly on the use of bioassaybased tests in which non-specificity is a major drawback. Moreover, although highly specific immunochemistrybased methods have been developed and routinely used as analytical tools in many areas of research, surprisingly the impact of these techniques in the bacteriocin research field has been marginal (Suárez et al., 1996a). Although other reports have described the generation of antibodies against nisin A and nisin Z (Falahaee et al., 1990; Stringer et al., 1995; Suárez et al., 1996a, b; Bouksaim et al., 1997), pediocin AcH (Bhunia et al., 1990), and against pediocin RS2 (Bhunia, 1994), antibodies were generated against the whole bacteriocin molecule either alone or conjugated to a carrier protein. However, the lack of purified bacteriocins means the availability of these molecules for use as immunogens is poor and the low molecular masses $(<5000 \mathrm{Da})$ of these compounds make them poorly immunogenic or non-immunogenic. In addition, peculiar characteristics of bacteriocin molecules, such as their hydrophobicity, the formation of intrachain disulfur rings and, in the case of lantibiotics, the presence of modified amino acids, might also interfere with the development of immunoassays. Antibodies generated against a short chemically synthesized fragment of a bacteriocin of interest may be useful to generate antibodies of predetermined specificity (Martínez et al., 1998).

Since PedA1 belongs to the pediocin family of bacteriocins, it exhibits strong amino acid sequence homology with other bacteriocins at the $\mathrm{N}$ terminus (Table 2). Moreover, since the PH1 fragment was evaluated to be a highly potential immunogenic fragment, according to its hydrophilicity and antigenic index determined by the use of the sequence analysis software package (Devereux et al., 1984), antibodies generated against such a fragment could behave as specific for PedA1 or could display a significant cross-reactivity against other Class IIa bacteriocins, making them valuable for detection, quantification and/or immunopurification of a large number of bacteriocins. Accordingly, the sensitivity and specificity of antibodies generated against the 1-9-N-terminal amino acid fragment of mature PedA1 were evaluated against closely related bacteriocins through the development of sensitive immunoassays.

The specificity of PH1-KLH-generated polyclonal antibodies for PedA1 was evaluated by NCI-, CI-, CD- and S-ELISA, protein slot-blotting and Western blotting. The limit of detection of PedA1 in NCI-ELISA (Fig. 1) was lower in $\mathrm{CB}$ than in MRS broth, reflecting the masking effect of the latter in the detection of PedA1 in this assay. Results obtained with CI-ELISA clearly indicated that coating of the plates with PedA1 instead of PH1-OAG enhanced the detection of free PedA1 (Fig. 2). Moreover, the limit of detection of the immunoassay was improved to $0 \cdot 01 \mu \mathrm{g}$ PedA $1 \mathrm{ml}^{-1}$ in MRS broth and $0.01-0.025 \mu \mathrm{g} \mathrm{ml} l^{-1}$ in PBS, and the $50 \%$ binding inhibition was achieved with $0 \cdot 1 \mu \mathrm{g}$ PedA $1 \mathrm{ml}^{-1}$ in MRS broth and $2.5 \mu \mathrm{g} \mathrm{ml}^{-1}$ in PBS. As shown also in Fig. 2, the competition curves for PedA1 in PBS and MRS broth differed notably, showing higher binding inhibition values in MRS broth. This effect was also observed with antibodies against the C-terminal fragment of PedA1 (Martínez et al., 1998). The limit of detection and sensitivity of NCI- and CI-ELISA developed for PedA1 were in the range of the values reported for nisin $\mathrm{A}$ 
(Falahaee et al., 1990; Suárez et al., 1996a, b) but were more effective than those obtained for pediocin RS2 (Bhunia, 1994).

However, contrary to what has been observed with antibodies against nisin A (Suárez et al., 1996a, b) and against the C-terminal fragment of PedA1 (Martínez et al., 1998), PedA1 did not effectively compete with either PH1-HRP or PedA1-HRP for binding to the antibodycoated microtitre wells in CD-ELISA. These results heighten the importance of the development of proper immunoassay formats for detection of each bacteriocin and confirm our previous observation that mice serum and ascites antibodies against the PH1-KLH conjugate did not recognize the whole PedA1 molecule by the use of CD-ELISA (Martínez et al., 1997). Similarly, the development of S-ELISA for evaluation of the specificity of PH1-KLH-generated antibodies for PedA1 was also unsuccessful. It is possible that because of the short length of PedA1, the capture antibodies against its $\mathrm{N}$ terminal end mask the recognition of the molecule by the detection antibodies generated against its C-terminal end.

PH1-KLH-generated antibodies showed a high affinity for PedA1 in the supernatants of $P$. acidilactici 347, Z102, A172 and X13 grown in MRS broth, and a small cross-reactivity to the supernatant of $P$. acidilactici $\mathrm{P} 20$ (Table 1), previously reported to harbour the pedA gene for production of PedA1 (Rodríguez et al., 1997). The antibodies did not show a significant cross-reactivity with cell culture supernatants from enterocin A, enterocin $\mathrm{P}$, sakacin $\mathrm{P}$ and sakacin A producer strains, bacteriocins which share the longer (KYYGNGxC) or shorter (YGNGVxC) consensus amino acid motifs with PedA1 (Table 2). This absence of cross-reactivity is not surprising, since it has been reported that closely related proteins have been distinguished by the use of antisera as probe for a specific substrate within the protein molecule (Groome, 1994) and that changes in a single amino acid residue drastically affects protein recognition (Rolland et al., 1995). PedA1 produced by $P$. acidilactici 347, Z102, A172, X13 and P20 grown in MRS broth was quantified by CI-ELISA (Table 3). The lower level of production of PedA1 by $P$. acidilactici P20 may be reasonably explained by genetic defects perhaps affecting expression, processing or secretion of this bacteriocin. The use of PH1-KLH-generated antibodies as probe for the identification and quantification of PedA1 in the supernatants of bacteriocin-producing strains, may be valuable as a tool to avoid the use of complex biochemical techniques involved in the purification to homogeneity and determination of the amino acid sequence of unknown antimicrobial activities.

When the immunoreactivity of the PH1-KLH-generated antibodies was evaluated by protein slot-blotting, the antibodies recognized PedA1 at a detection limit of $5 \mu \mathrm{g}$ $\mathrm{ml}^{-1}$ (Fig. 4). The low level of detection of PedA1 in this assay compared to the other immunoassays may reflect differences in PedA1 solubility, conformation of the bacteriocin, preferential attachment of the bacteriocin to the membrane by its $\mathrm{N}$-terminal end, aggregation of the bacteriocin molecules with components of MRS broth and oxidation of amino acid residues. However, using the same assay and conditions, the limit of detection of PedA1 in MRS broth was found to be $2.5 \mu \mathrm{g}$ $\mathrm{ml}^{-1}$ when antibodies against the C-terminal end of PedA1 were used (Martínez et al., 1998). This allows us to hypothesize that perhaps the preferential attachment of PedA1 to the nitrocellulose membrane through its Nterminal end is masking in part the recognition of the molecule by PH1-KLH-generated antibodies. When the immunoreactivity of the rabbit polyclonal antibodies to PedA1 was ascertained by Western blotting, the limit of detection of PedA1 was determined to be $0.01 \mu \mathrm{g} \mathrm{ml}^{-1}$ (Fig. 5a). The absence of cross-reactivity of the antibodies against the supernatants of various pediocin-like bacteriocin producer or non-producer LAB strains heightens the importance and significance of the Western blotting technique for the rapid detection and identification of PedA1 in the supernatants of producer strains.

The strategy of using a synthetic peptide for generating antibodies against a bacteriocin epitope(s) sharing a highly conserved amino acid sequence with closely related bacteriocins has been shown to be both conceptually simple and practically convenient. Furthermore, the sensitivity and specificity of PH1-KLHgenerated rabbit polyclonal antibodies for PedA1 and the absence of cross-reactivity against Class IIa bacteriocins or other bacteriocins, either lantibiotic or non-lantibiotic, suggest that all the techniques described here for selection of the peptide fragment, carrier molecule, conjugation methods and immunoassay development can be used as models for the generation of antibodies against other bacteriocins of interest in the food industry. Potential specific applications of these antibodies include the rapid identification and isolation of PedA1 producer strains from many sources, an application based on reports on the production of PedA1 by a vegetable-associated Pediococcus parvulus strain (Bennik et al., 1997) and by Lactobacillus plantarum WHE 92 isolated from cheese (Ennahar et al., 1996). The PH1-KLH-generated antibodies may also serve as a tool for studies on the regulation of PedA1 production, processing-secretion, identification of target cell specificity-determining regions, evaluation of structurefunction relationships and analysis by ELISA of PedA1 in foods. Of great interest is the availability of specific antibodies to well characterized bacteriocins for studies on the expression of different bacteriocins in heterologous hosts (Horn et al., 1998; N. Horn, M. I. Martínez, J. M. Martínez, P. E. Hernández, M. J. Gasson, J. M. Rodríguez \& H. Dodd, unpublished results). The antibodies described in this work can also be used for the purification of PedA1 to homogeneity in a single step by immunoaffinity chromatography.

\section{ACKNOWLEDGEMENTS}

This work was partially supported by grant ALI97-0559 from the Comisión Interministerial de Ciencia y Tecnología (CICYT), Madrid, Spain, and by contract BIOT-CT94-3055 from The Commission of the European Communities. 
J.M.M. holds a fellowship from the Comunidad Autónoma de Madrid, M.I.M. is a researcher working under the European Contract and C.H. is the recipient of a fellowship from the Ministerio de Educación y Ciencia, Madrid, Spain. We are grateful to J. Vázquez (Centro de Biología Molecular Severo Ochoa, Madrid, Spain) for the chemical synthesis of the peptide fragments. We acknowledge J. Kok, J. W. Sanders and H. Karsens (Department of Genetics, University of Groningen, The Netherlands) for providing Lb. sakei ATCC 15521 and for training in the overlay assay and Western blotting, and Professor I. F. Nes (Laboratory of Microbial Gene Technology, Agricultural University, As, Norway) for providing other $L b$. sakei strains.

\section{REFERENCES}

Abriouel, H., Valdivia, E., Gálvez, A. \& Maqueda, M. (1998). Response of Salmonella cholerasuis LT2 spheroplasts and permeabilized cells to the bacteriocin AS-48. Appl Environ Microbiol 64, 4623-4626.

Avrameas, S. \& Ternynck, T. (1969). The cross-linking of proteins with glutaraldehyde and its use for the preparation of immunoadsorbents. Immunochemistry 6, 53-56.

Aymerich, T., Holo, H., Havarstein, L. S., Garriga, M. \& Nes, I. F. (1996). Biochemical and genetic characterization of enterocin A from Enterococcus faecium, a new antilisterial bacteriocin in the pediocin family of bacteriocins. Appl Environ Microbiol 62, 1676-1682.

van Belkum, M. J., Worobo, R. W. \& Stiles, M. (1997). Doubleglycine-type leader peptides direct secretion of bacteriocins by ABC transporters: colicin V secretion in Lactococcus lactis. Mol Microbiol 23, 1293-1301.

Bennik, M. H. J., Smid, E. J. \& Gorris, L. G. M. (1997). Vegetableassociated Pediococcus parvulus produces pediocin PA-1. Appl Environ Microbiol 63, 2074-2076.

Bennik, M. H. J., Vanloo, B., Brasseur, R., Gorris, L. G. M. \& Smid, E. J. (1998). A novel bacteriocin with a YGNGV motif from vegetable-associated Enterococcus mundtii: full characterization and interaction with target organisms. Biochim Biophys Acta 1373, 47-58.

Bhugaloo-Vial, P., Dousset, X., Metivier, A., Sorokine, O., Anglade, P., Bogaval, P. \& Marion, D. (1996). Purification and amino acid sequences of piscicocins V1a and V1b, two class IIa bacteriocins secreted by Carnobacterium piscicola V1 that display significant levels of specific inhibitory activity. Appl Environ Microbiol 62, 4410-4416.

Bhunia, A. K. (1994). Monoclonal antibody-based enzyme immunoassay for pediocins of Pediococcus acidilactici. Appl Environ Microbiol 60, 2692-2696.

Bhunia, A. K., Johnson, M. C. \& Ray, B. (1987). Direct detection of an antimicrobial peptide of Pediococcus acidilactici in sodium dodecyl sulfate-polyacrylamide gel electrophoresis. $J$ Ind Microbiol 2, 319-322.

Bhunia, A. K., Johnson, M. C., Ray, B. \& Elden, E. L. (1990). Antigenic property of pediocin AcH produced by Pediococcus acidilactici H. J Appl Bacteriol 69, 211-215.

Biet, F., Berjeaud, J. M., Worobo, R. W., Cenatiempo, Y. \& Fremaux, C. (1998). Heterologous expression of the bacteriocin mesentericin Y105 using the dedicated transport system and the general secretion pathway. Microbiology 144, 2845-2854.

Bouksaim, M., Fliss, I., Meghrous, J., Simard, R. \& Lacroix, C. (1998). Immunodot detection of nisin $Z$ in milk and whey using enhanced chemiluminescence. J Appl Microbiol 81, 176-184.
Briand, J. P., Muller, S. \& van Regenmortel, M. H. V. (1985). Synthetic peptides as antigens: pitfalls of conjugation methods. $J$ Immunol Methods 78, 59-69.

Casaus, P., Nilsen, T., Cintas, L. M., Nes, I. F., Hernández, P. E. \& Holo, H. (1997). Enterocin B, a new bacteriocin from Enterococcus faecium T136 which can act synergistically with enterocin A. Microbiology 143, 2287-2294.

Cintas, L. M., Casaus, P., Havarstein, L. S., Hernández, P. E. \& Nes, I. F. (1997). Biochemical and genetic characterization of enterocin $\mathrm{P}$, a novel sec-dependent bacteriocin from Enterococcus faecium P13 with a broad antimicrobial spectrum. Appl Environ Microbiol 63, 4321-4330.

Cintas, L. M., Casaus, P., Holo, H., Hernández, P. E., Nes, I. F. \& Havarstein, L. S. (1998). Enterocins L50A and L50B, two novel bacteriocins from Enterococcus faecium L50, are related to staphylococcal hemolysins. J Bacteriol 180, 1988-1994.

Devereux, J., Haeberli, P. \& Smithies, O. (1984). A comprehensive set of sequence analysis programs for the VAX. Nucleic Acids Res 12, 387-395.

Ennahar, S., Aoude-Werner, D., Sorokine, O., van Dorsselaer, A., Bringel, F., Hubert, J.-C. \& Hasselmann, C. (1996). Production of pediocin AcH by Lactobacillus plantarum WHE 92 isolated from cheese. Appl Environ Microbiol 62, 4381-4387.

Falahaee, M. B., Adams, M. R., Dale, J. W. \& Morris, B. A. (1990). An enzyme immunoassay for nisin. Int J Food Sci Technol 25, 590-595.

Gasson, M. J. (1983). Plasmid complements of Streptococcus lactis NCDO712 and other lactic streptococci after protoplastinduced curing. J Bacteriol 154, 1-9.

Groome, N. P. (1994). Immunoassays of proteins and anti-peptide antibodies. In Peptide Antigens: A Practical Approach, pp. 139-179. Edited by G. R. Wisdom. Oxford: IRL Press.

Henderson, J. T., Chopko, A. L. \& Wassenaar, P. D. (1992). Purification and primary structure of pediocin PA-1 produced by Pediococcus acidilactici PAC1.0. Arch Biochem Biophys 295, 5-12.

Holck, A., Axelsson, L., Birkeland, S. E., Aukrust, T. \& Blom, H. (1992). Purification and amino acid sequence of sakacin $A$, a bacteriocin from Lactobacillus sake Lb706. J Gen Microbiol 138, 2715-2720.

Horn, N., Martínez, M. I., Martínez, J. M., Hernández, P. E., Gasson, M. J., Rodríguez, J. M. \& Dodd, H. (1998). Production of pediocin PA-1 by Lactococcus lactis using the lactococcin A secretory apparatus. Appl Environ Microbiol 64, 818-823.

Jack, R. W., Tagg, J. R. \& Ray, B. (1995). Bacteriocins of Grampositive bacteria. Appl Environ Microbiol 59, 171-200.

Klaenhammer, T. R. (1993). Genetics of bacteriocins produced by lactic acid bacteria. FEMS Microbiol Rev 12, 39-86.

Leistner, L. \& Gorris, L. G. M. (1995). Food preservation by hurdle technology. Trends Food Sci Technol 6, 41-46.

Martínez, M. l., Rodríguez, J. M., Suárez, A., Martínez, J. M., Azcona, J. I. \& Hernández, P. E. (1997). Generation of polyclonal antibodies against a chemically synthesized $\mathrm{N}$-terminal fragment of the bacteriocin pediocin PA-1. Lett Appl Microbiol 24, 488-492.

Martínez, J. M., Martínez, M. I., Suárez, A. M., Herranz, C., Casaus, P., Cintas, L. M., Rodríguez, J. M. \& Hernández, P. E. (1998). Generation of polyclonal antibodies of predetermined specificity against pediocin PA-1. Appl Environ Microbiol 64, 4536-4545.

Marugg, J. D., Gonzalez, C. F., Kunka, B. S., Ledeboer, A. M., Pucci, M. J., Toonen, M. Y., Walker, S. A., Zoetmulder, L. C. M. \& 
Vanderbergh, P. A. (1992). Cloning, expression and nucleotide sequence of genes involved in production of pediocin PA-1, a bacteriocin from Pediococcus acidilactici PAC1.0. Appl Environ Microbiol 58, 2360-2367.

Metivier, A., Pilet, M. F., Dousset, X., Sorokine, O., Anglade, P., Zagorec, M., Piard, J. C., Marion, D., Cenatiempo, Y. \& Fremaux, C. (1998). Divercin V41, a new bacteriocin with two disulphide bonds produced by Carnobacterium divergens V41: primary structure and organization. Microbiology 144, 2837-2844.

Nakane, P. K. \& Kawoi, A. (1974). Peroxidase-labelled antibody: a new method of conjugation. J Histochem Cytochem 22, 1084-1091.

Nes, I. F., Diep, D. B., Håvarstein, L. S., Brueberg, M. B., Eijsink, V. \& Holo, H. (1996). Biosynthesis of bacteriocins in lactic acid bacteria. Antonie Leeuwenhoek 70, 113-128.

Nieto Lozano, J. C., Nissen Meyer, J., Sletten, K., Pelaez, C. \& Nes, I. F. (1992). Purification and amino acid sequence of a bacteriocin produced by Pediococcus acidilactici. J Gen Microbiol 138, 1985-1990.

Nissen-Meyer, J. \& Nes, I. F. (1997). Ribosomally synthesized antimicrobial peptides: their function, biosynthesis and mechanism of action. Arch Microbiol 167, 67-77.

Piva, A. \& Headon, D. H. (1994). Pediocin A, a bacteriocin produced by Pediococcus pentosaceus FBB61. Microbiology 140, 697-702.

Rodríguez, J. M., Cintas, L. M., Casaus, P., Suárez, A. \& Hernández, P. E. (1995a). PCR detection of the lactocin S structural gene in bacteriocin-producing lactobacilli from meat. Appl Environ Microbiol 61, 2802-2805.

Rodríguez, J. M., Cintas, L. M., Casaus, P., Horn, N., Dodd, H. M., Hernández, P. E. \& Gasson, M. J. (1995b). Isolation of nisinproducing Lactococcus lactis strains from dry fermented sausages. J Appl Bacteriol 78, 109-115.

Rodríguez, J. M., Cintas, L. M., Martínez, M. I., Casaus, P., Suárez,
A. M. \& Hernández, P. E. (1997). Detection of pediocin PA-1 producing pediococci by rapid molecular biology procedures. Food Microbiol 14, 363-371.

Rolland, M. P., Bitri, L. \& Besancon, P. (1995). Monospecificity of the antibodies to bovine $\alpha_{\mathrm{s} 1}$-casein fragment 140-149: application to the detection of bovine milk in caprine dairy products. J Dairy Res 62, 83-88.

Shägger, H. \& Von Jagow, G. (1987). Tricine-sodium dodecyl sulfate-polyacrylamide gel electrophoresis for the separation of proteins in the range of 1 to $100 \mathrm{kDa}$. Anal Biochem 166, 368-379.

Stringer, S. C., Dodd, C. E. R., Morgan, M. R. A. \& Waites, W. M. (1995). Locating nisin-producing Lactococcus lactis in a fermented meat system. J Appl Bacteriol 78, 341-348.

Suárez, A. M., Rodríguez, J. M., Hernández, P. E. \& AzconaOlivera, J. I. (1996a). Generation of polyclonal antibodies against nisin: immunization strategies and immunoassays development. Appl Environ Microbiol 62, 2117-2121.

Suárez, A. M., Rodríguez, J. M., Morales, P., Hernández, P. E. \& Azcona-Olivera, J. I. (1996b). Development of monoclonal antibodies to the lantibiotic nisin A. J Agric Food Chem 44, 2936-2940.

Suárez, A. M., Azcona, J. l., Rodríguez, J. M., Sanz, B. \& Hernández, P. E. (1997). One-step purification of nisin A by immunoaffinity chromatography. Appl Environ Microbiol 63, 4990-4992.

Tichaczek, P. S., Vogel, R. F. \& Hammes, W. P. (1994). Cloning and sequencing of sakP encoding sakacin $\mathrm{P}$, the bacteriocin produced by Lactobacillus sake LTH673. Microbiology 140, 361-370.

Venema, K., Kok, J., Marugg, J. D., Toonen, M. Y., Ledeboer, A. M., Venema, G. \& Chikindas, M. L. (1995). Functional analysis of the pediocin operon of Pediococcus acidilactici PAC1.0: PedB is the immunity protein and $\mathrm{PedD}$ is the precursor processing enzyme. Mol Microbiol 17, 515-522.

Received 8 March 1999; revised 28 May 1999; accepted 25 June 1999. 